\title{
Characterization and Impact of Cattle Manure Particle Size on Physical Properties of Sandy Soils
}

\section{-Study of Cattle Manure Particle Size Impact on the Physical Properties of Sandy Soil}

\author{
Doaa Ahmed El-Nagar ${ }^{*}$, Ramadan Abd Alaaty Mohamed ${ }^{2}$ \\ ${ }^{1}$ Soil Improvement Department, Soil, Water and Environment Institute (Agricultural Research Center), Egypt \\ ${ }^{2}$ Vegetable Crops Department, Horticulture Research Institute (Agricultural Research Center), Egypt \\ Email: *elnagar.doaa@yahoo.com,ramadan_mohamed12@yahoo.com
}

How to cite this paper: El-Nagar, D. A., \& Mohamed, R. A. A. (2019). Characterization and Impact of Cattle Manure Particle Size on Physical Properties of Sandy Soils. Journal of Geoscience and Environment Protection, 7, 180-194.

https://doi.org/10.4236/gep.2019.78013

Received: June 22, 2019

Accepted: August 20, 2019

Published: August 23, 2019

Copyright (๑) 2019 by author(s) and Scientific Research Publishing Inc. This work is licensed under the Creative Commons Attribution International License (CC BY 4.0).

http://creativecommons.org/licenses/by/4.0/

(c) (i) Open Access

\begin{abstract}
Sandy soils have poor physical properties, which cause them to drain quickly and not hold water well; however, with the addition of cattle manure, sandy soil can be improved. Therefore, experiments were conducted to investigate the characterization and impact of different particle sizes of cattle manure (CMS) on improving some physical properties of sandy soil and thus the yield of lettuce. Cattle manure was ground to powder and was sieved with three different Particle sizes 4.76-2 (CMS1), 2-0.8 (CMS2), 0.8-0.4 (CMS3) $\mathrm{mm}$. Some physical properties were measured for different Particle sizes of manure. A batch of sorption experiments was carried out to study the role of different Particle sizes of manure on adsorption of $\mathrm{N}, \mathrm{P}$ and $\mathrm{K}$ from aqueous solution. Two experiments were carried out on sandy soil (pots and field) to study the impact of adding CMS (5 ton/fed) to enhance some physical properties of sandy soil. The results indicated that the physical properties of cattle manure changed based on particle size fractionation, where Bulk density and saturated water holding capacity increased as particle size decreased, while porosity reduced as particle size decreased. The results of the sorption parameters of $\mathrm{N}, \mathrm{P}$ and $\mathrm{K}$ on different particle sizes of manure indicated that maximum sorption occurred on CMS 3 for both $\mathrm{P}$ and $\mathrm{K}$ according to Langmuir and Freundlich sorption models. Two experiments showed that CMS had affected significantly the total porosity (TP), bulk density (Bd), slowly drainable pores (SDP), water holding pores and (WHP) available water (AW) in comparison to control. The CMS had a slight effect on Quickly-drainable pores (QDP) and fine capillary pores (FCP) as compared to the control in
\end{abstract}


both experiments. Fresh weight, dry weight and number of leaf lettuce increased significantly with decreasing particle sizes of cattle manure as compared to control.

\section{Keywords}

Cattle Manure, Size, Soil Properties, Langmuir and Freundlich Sorption Models

\section{Introduction}

Sandy soil is widely found in arid and semi-arid regions in the west and east desert areas of Egypt. Texture sandy soils are composed of more than $68 \%$ sand, and less than $18 \%$ clay in the first $100 \mathrm{~cm}$ (ISSS Working Group, 1998). It is very difficult to manage sandy soils because they easily lose nutrients by leaking and are highly prone to corrosion due to poor aggregation (Burt et al., 2001). Therefore, the fertility level of this soil is very poor (Kheir et al., 2016). Physical properties of sandy soil are easily identifiable: weak or no structure, high permeability, high infiltration rate, poor Aggregate stability and poor water retention capacity (Van Asperen et al., 2014; Bhanu et al., 2018). Increasing productive lands is one of the major targets of the agricultural policy. In the case of sandy soils is limited due to inert chemical and biological conditions.

Applying organic materials to soil not only creates a better nutritional state, but also positively influences physical properties of soil, such as soil particles aggregation, water retention properties, hydraulic conductivity, bulk density, porosity, available water and airing, and reduces the rate of erosion (Diana et al., 2008; Mylavarapu \& Zinati, 2009; Arthur et al., 2011; Giorgio et al., 2019). The water management and nutrient-supply of sandy soil are significantly improved by organic matter treatment (Celik et al., 2004; Monica et al., 2011); also enhanced the overall sandy soil microbial activity, especially of the desirable groups (Monica et al., 2011). Organic amendments may increase crop yields by improving soil nutrient availability and resilience of soil structures in addition to high water retention during the crop growth period (Jiang et al., 2018). Agricultural and animal wastes, rather than throw them, can provide a cheap alternative source of organic matter to improvement of soil fertility (Mubarak et al., 2009).

The main supplier in this regard is cattle manure (Bayu et al., 2005; Rasoulzadeh \& Yaghoubi, 2014); supplying nutrients, increasing organic matter, increasing cation exchange capacity (Bakayoko et al., 2009) and improving soil physical properties such as porosity, soil bulk density, particle density, infiltration, hydraulic conductivity, stability of aggregates and available water capacity, application of cattle manure showed positive effect on physical soil properties (Rasoulzadeh \& Yaghoubi, 2010). The physical and chemical properties of organic matter were changed by Particle size fractionation ( 1.6 to $0.1 \mathrm{~mm}$ ), where there is a 
trend to improve some soil parameters as bulk density, porosity, saturated water holding capacity, $\mathrm{pH}$, organic content, and $\mathrm{Ca}, \mathrm{Fe}, \mathrm{Mg}$ and $\mathrm{Mn}$ contents with the decrease of particle size (Shulan et al., 2012). The finer composts release nutrients faster than coarse compost (Lata Verma \& Marschner, 2013). The objective of this study was to evaluate the impact of adding of different particle sizes of cattle manure on improve some physical properties of sandy soil, nutrient holding capacity of soils and it is effect on the productivity yield of lettuce.

\section{Materials and Methods}

The cattle manure was air-dried, ground and sieved with three different particle sized meshes to obtain 4.76-2 (CMS1), 2-0.8 (CMS 2), 0.8-0.4 (CMS 3) mm and (CM) without grinding. Total nitrogen in CMS digestion determined by Kjeldahl method according to (Cotteine et al., 1982). Total P, K in CMS determined by wet digestion according to (Cottenie et al., 1982), and total P determined by Inductively Coupled Plasma Spectrometry (Ultima 2 JY Plasma) (Ivajlo et al., 2008). Also total K was determined by flame photometer. Organic matter content was determined according to Walkley and Black Method (Black, 1982). The properties of the used CMS illustrated in Table 1.

Table 1. Some chemical properties of CMS.

\begin{tabular}{ccccc}
\hline Properties & CM & CMS1 & CMS2 & CMS3 \\
\hline N \% & 7.00 & 6.99 & 7.50 & 7.8 \\
P \% & 0.89 & 0.91 & 0.99 & 0.9 \\
K \% & 5.05 & 4.88 & 5.70 & 5.5 \\
OM \% & 37.80 & 38.00 & 38.09 & 38.7 \\
\hline
\end{tabular}

\subsection{Batch Biosorption of Different Particle Sizes of Manure}

A batch sorption experiments were carried out to study the role of different Particle sizes of manure on adsorption of $\mathrm{N}, \mathrm{P}$ and $\mathrm{K}$ from aqueous solution. The stock solutions of the $\mathrm{N}, \mathrm{P}$ and $\mathrm{K}$ used in this study was $(1000 \mathrm{mg} / \mathrm{l})$. Subsequent dilutions of $(10,20,30,40$, and $50 \mathrm{mg} / \mathrm{l})$ were prepared by suitably diluting stock solution with double distilled water. The experiments were performed in $100 \mathrm{ml}$ flasks containing $50 \mathrm{ml}$ of $\mathrm{N}, \mathrm{P}$ and $\mathrm{K}$ of different concentration plus $2 \mathrm{~g}$ manure with four different sizes, and with four replicates for each experiment. The mixture was shaken in a rotary shaker at $50 \mathrm{rpm}$ for one hour followed by filtration using Whatman filter paper (No. 1). The filtrate containing the residual concentration of $\mathrm{N}, \mathrm{P}$ and $\mathrm{K}$ was stored for analysis.

According to (Vijayaraghavan et al., 2006) the equilibrium sorption capacity of $\mathrm{N}, \mathrm{P}$ and $\mathrm{K}$ was calculated by:

$$
S=\frac{\left(C_{0}-C_{e}\right) \times V}{m}
$$


where; $S$ is equilibrium N, P and $\mathrm{K}$ ions capacity $(\mathrm{mg} / \mathrm{g}), C_{e}$ and $C_{0}$ are the concentrations $(\mathrm{mg} / \mathrm{l})$ of the metals in the initial solution and the equilibrium solution after the experiment, respectively, $\mathrm{V}(\mathrm{l})$ is the volume of the solution and $\mathrm{m}$ (g) the amount of different sizes of manure used.

The sorption data were fitted to some sorption models such as Langmuir and Freundlich isotherm models using software IsoFit (Matott, 2007).

Langmuir equation

$$
q_{e}=\frac{q_{m} K_{L} C_{e}}{1+K_{L} C_{e}}
$$

where, $C_{e}$ is the supernatant concentration at the equilibrium state of the system (mg/l), $q_{m}$ and $K_{L}$ are the Langmuir constants, representing the maximum adsorption capacity for the solid phase loading and the energy constant related to the heat of adsorption respectively.

Freundlich equation

$$
q_{e}=K_{F} C_{e}^{1 / n}
$$

where, $K_{F}$ and $n$ are adsorption capacity and affinity, respectively.

\subsection{Some Physical Properties of Different Particle Sizes of Cattle Manure}

Samples of cattle manure were replicated five times, in order to determine some physical properties of different sizes manure, such, Bulk density $(\mathrm{Bd})\left(\mathrm{g} / \mathrm{cm}^{3}\right)=$ dry weight/volume, Particle density (Pd) according to (Blake \& Hartge, 1986). Total porosity $(\mathrm{TP})$ was calculated $(\%)=(1-\mathrm{Bd} / \mathrm{Pd}) \times 100$ according to (Klute, 1986). The water holding capacity (WHC) (\% volume) was also calculated as [(wet weight - dry weight)/volume] $\times 100$ (Inbar et al., 1993).

\subsection{Pots Experiment}

Study effect of different Particle sizes of cattle manure (CMS) application on some physical properties of sandy soil (bulk density (Bd), total porosity (TP) field capacity (FC), wilting point (WP), available water (AW) and pore size distribution). Each pot contained $1.5 \mathrm{Kg}$ of soil. The soils mixed uniformly with the CMS at rate $5 \mathrm{tan} /$ fed and packed in plastic pots. Five treatments (control, manure without grinding (CM), 4.76-2 mm (CMS1), 2-0.8 mm (CMS2) and 0.8-0.4 $\mathrm{mm}$ (CMS3) were applied in five replicates by completely a randomized design. The amount of water for irrigation was measured each time by weighing pots, to reach the field capacity. Soil samples were taken from each pot after 60 days and were analyzed. The available water capacity (AW) calculated as difference between FC and WP. Pore size distribution calculated from $\mathrm{pF}$ curves according to (De-leenher \& De-Boodt, 1965).

\subsection{Field Experiment}

The experimental site arranged in Bader center, El-Beharia Governorate. It was 
sown at the 4th June 2018. Field experiment applied in a Randomized Complete Block Design. It comprised of (control, manure without grinding (CM), 4.76-2 mm (CMS 1), 2-0.8 mm (CMS 2) and 0.8-0.4 mm (CMS 3)) at level of manure 5 $\tan /$ fed with three replicates. The lettuce (Lactuca sativa) variety used was "Afram". Seedlings were planted at the age of four weeks after seeding. The plot dimension was $1.5 \mathrm{~m} \times 1.5 \mathrm{~m}\left(2.25 \mathrm{~m}^{2}\right)$ and there were 15 plots in total. Plant spacing was $30 \mathrm{~cm}$ between plants. Five plants were selected randomly from each plot after 60 days and the measurements were taken (fresh weight, dry weight and number of leaf). A soil sample taken from each plot after 60 days and analyzed for some physical properties (Pore size distribution, total porosity (TP), Bulk density and available water) (Table 2).

Table 2. Some physical and chemical properties of experiment soil studied.

\begin{tabular}{|c|c|}
\hline Properties & Soil \\
\hline \multicolumn{2}{|l|}{ Particle size distribution (\%) } \\
\hline Sand & 89 \\
\hline Clay & 2.5 \\
\hline Silt & 8.5 \\
\hline Textural class & Sandy \\
\hline $\mathrm{O} . \mathrm{M}, \%$ & 0.5 \\
\hline $\mathrm{CaCO}_{3}, \%$ & 0.66 \\
\hline $\mathrm{Ph}(1: 2.5)$ & 7.79 \\
\hline EC & 11.75 \\
\hline \multicolumn{2}{|l|}{ Soluble cations (meq/l) } \\
\hline $\mathrm{Ca}++$ & 29.3 \\
\hline $\mathrm{Mg}++$ & 27.3 \\
\hline $\mathrm{K}+$ & 58.9 \\
\hline $\mathrm{Na}+$ & 1.0 \\
\hline \multicolumn{2}{|l|}{ Soluble anions (meq/l) } \\
\hline $\mathrm{Cl}-$ & 113.4 \\
\hline $\mathrm{HCO}_{3}--$ & 1.3 \\
\hline $\mathrm{CO}_{3}--$ & 0 \\
\hline $\mathrm{SO}_{4}^{--}$ & 1.8 \\
\hline
\end{tabular}

\section{Results and Discussion}

\subsection{Batch Sorption of Different Particle Sizes of Manure}

The effect of initial metal concentration (N, P and K) on adsorption onto different particle sizes of manure are illustrated in Figures 1-3. It suggested that the biosorption capacity of $\mathrm{K}$ (at $50 \mathrm{mg} / \mathrm{l}$ ) increased with decreasing the particle size 
of manure (CM, CMS1, CMS2, and CMS3). It is account as 1211.7, 1214.5, 1221.5 and $1225.25 \mathrm{mg} / \mathrm{kg}$, respectively. It is apparently observed that the biosorption capacity (S) of $\mathrm{P}$ (at $50 \mathrm{mg} / \mathrm{l}$ ) in manure with four different sizes were $1248.2,1248.25,1248.22$ and $1248.42 \mathrm{mg} / \mathrm{kg}$, respectively. The maximum Biosorption capacity of $\mathrm{N}$ by these ingredients were 1246.5, 1247.1, 1247.13 and $1246.8 \mathrm{mg} / \mathrm{kg}$, respectively. The results indicated that Biosorption capacity of manure with four different sizes increased with an increase in the initial concentration of $\mathrm{N}, \mathrm{P}$ and $\mathrm{K}(50 \mathrm{mg} / \mathrm{l})$. These results may be due to the functional groups present offer certain forces of attractions for the metal ions and provide a high efficiency for their adsorption in manure. These finding are in agreement with the findings of (Rajashekhar et al., 2017; Eshwar et al., 2017) who found that the manures was content fulvic acid, carboxyl groups and phenolic $-\mathrm{OH}$ groups.

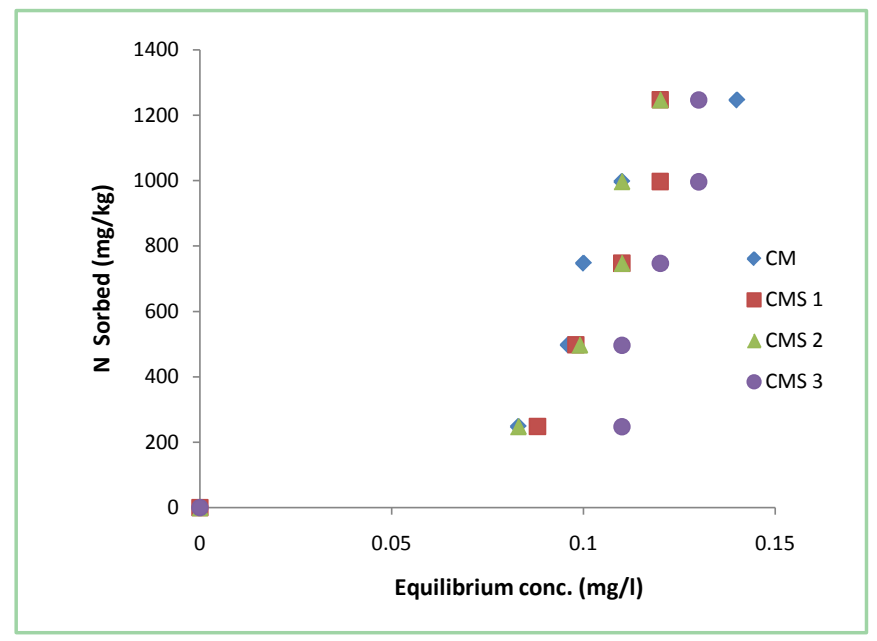

Figure 1. Equilibrium concentration $(\mathrm{mg} / \mathrm{l})$ of $\mathrm{N}$ at different particle sizes of manure.

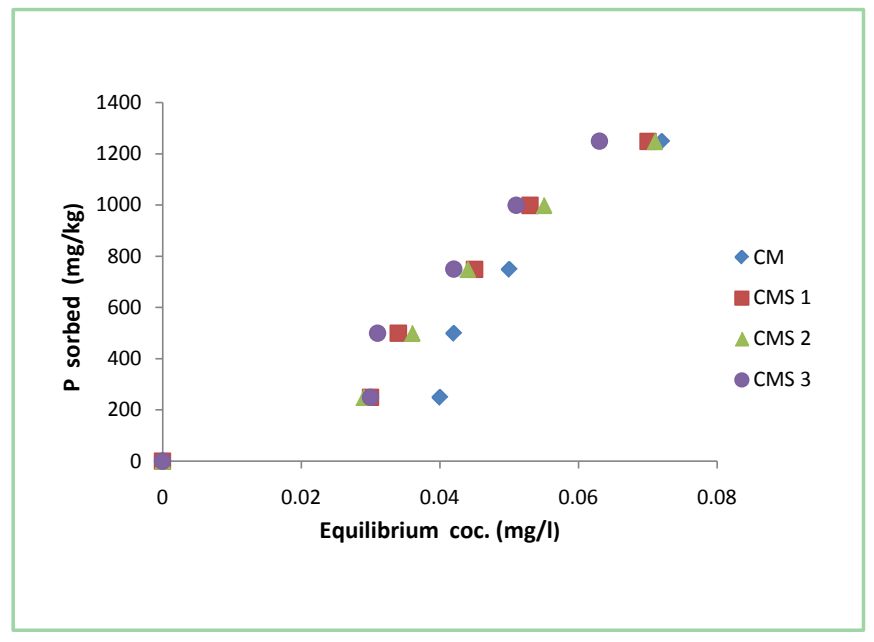

Figure 2. Equilibrium concentration ( $\mathrm{mg} / \mathrm{l})$ of $\mathrm{P}$ at different particle sizes of manure. 


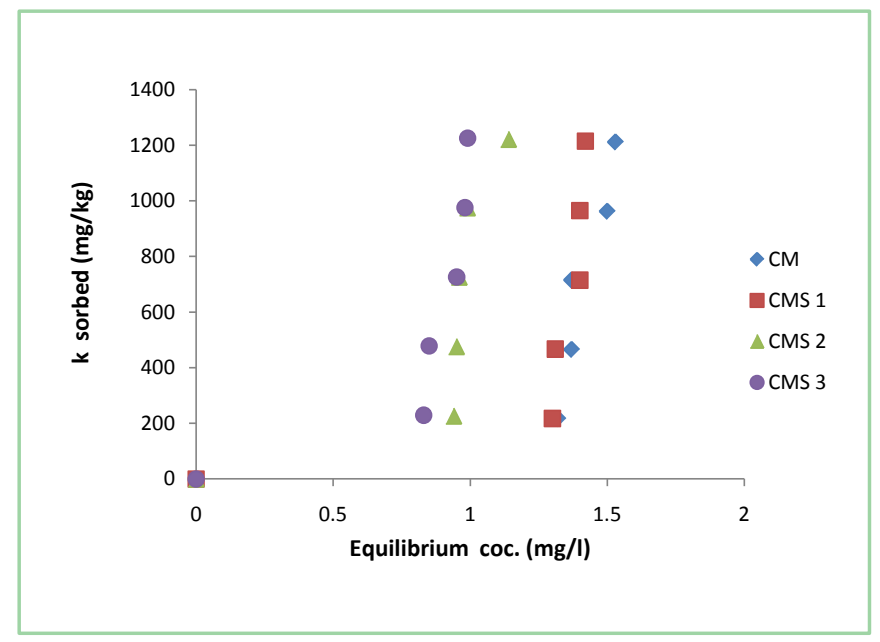

Figure 3. Equilibrium concentration $(\mathrm{mg} / \mathrm{l})$ of $\mathrm{K}$ at different particle sizes of manure.

The experimental data (sorption isotherm) obtained from the batch studies of $\mathrm{N}, \mathrm{P}$ and $\mathrm{K}$ on different particle sizes of manure were modeled using various simple adsorption models such as Langmuir and Freundlich models (Table 3). The results show the sorption parameters of $\mathrm{N}, \mathrm{P}$ and $\mathrm{K}$ on different particle sizes of manure indicated that maximum sorption of was occurred on CMS 3 for both $\mathrm{P}$ and $\mathrm{K}$ according to Langmuir and Freundlich sorption models. The CMS 3 has more ability for retention of such as $\mathrm{P}$ and $\mathrm{K}$. The partition coefficient was $1.8 \mathrm{~L} / \mathrm{kg}$ for $\mathrm{P}$ and $8.12 \mathrm{~L} / \mathrm{kg}$ for $\mathrm{K}$, indicated that $\mathrm{K}$ is more binding on such materials than $\mathrm{N}$ and $\mathrm{P}$. The results indicated that optimum size of manure is 0.8-0.4 mm; it has maximum sorption of both $\mathrm{K}$ and $\mathrm{P}$ because of their high reactivity due to the large surface to volume ratio leading to improve efficiency of nutrient adsorption. These results were in agreement with (Aryanpour et al., 2017). The maximum sorption of $\mathrm{N}$ occurred on CMS 2. The partition coefficient was $7.44 \mathrm{~L} / \mathrm{kg}$.

Table 3. Parameters of some sorption isotherm models of N, P and K on different particle sizes of manure.

\begin{tabular}{cccccc}
\hline Sorption model & Treatment & Parameters & $\mathrm{N}$ & $\mathrm{P}$ & $\mathrm{K}$ \\
\hline \multirow{3}{*}{ Langmuir } & & $\mathrm{KL}$ & 1.25 & 1.15 & 1.03 \\
& $\mathrm{CM}$ & $\mathrm{qm}$ & 7.39 & 1.53 & 5.15 \\
& & $\mathrm{R} 2$ & 0.89 & 0.82 & 0.90 \\
& $\mathrm{CMS} 1$ & $\mathrm{KL}$ & 3.7 & 5.15 & 2.3 \\
& & $\mathrm{qm}$ & 7.24 & 1.6 & 5.3 \\
& & $\mathrm{R} 2$ & 0.94 & 0.95 & 0.86 \\
& & $\mathrm{KL}$ & 3.96 & 6.4 & 1.6 \\
& $\mathrm{CMS} 2$ & $\mathrm{qm}$ & 7.44 & 1.66 & 7.4 \\
& & $\mathrm{R} 2$ & 0.91 & 0.97 & 0.70 \\
\hline
\end{tabular}




\section{Continued}

\begin{tabular}{|c|c|c|c|c|c|}
\hline & & KL & 2.86 & 4.06 & 2,07 \\
\hline & CMS 3 & $\mathrm{qm}$ & 6.39 & 1.8 & 8.12 \\
\hline & & $\mathrm{R} 2$ & 0.90 & 0.95 & 0.90 \\
\hline & & $\mathrm{Kf}$ & 7.39 & 1.53 & 5.15 \\
\hline \multirow[t]{11}{*}{ Freundlich } & $\mathrm{CM}$ & $1 / \mathrm{n}$ & 1.0 & 1.0 & 1.0 \\
\hline & & $\mathrm{R} 2$ & 0.89 & 0.83 & 0.90 \\
\hline & & $\mathrm{Kf}$ & 7.24 & 1.68 & 5.32 \\
\hline & CMS 1 & $1 / \mathrm{n}$ & 1.0 & 1.0 & 0.99 \\
\hline & & $\mathrm{R} 2$ & 0.93 & 0.95 & 0.85 \\
\hline & & Kf & 7.44 & 1.66 & 7.4 \\
\hline & CMS 2 & $1 / \mathrm{n}$ & 1.0 & 1.0 & 1.0 \\
\hline & & R2 & 0.91 & 0.97 & 0.71 \\
\hline & & $\mathrm{Kf}$ & 6.39 & 1.8 & 8.12 \\
\hline & CMS 3 & $1 / \mathrm{n}$ & 1.0 & 0.99 & 0.99 \\
\hline & & R2 & 0.90 & 0.95 & 0.90 \\
\hline
\end{tabular}

\subsection{Some Physical Properties of Different Particle Sizes of Manure}

The bulk density (Bd) and water-holding capacity (WHC) increased as particle size decreased, significantly higher Bd and WHC were 0.8-0.4 mm CMS3 (Table 4). The values of the CMS 3 bulk density suggest that these cattle manure fractions have less pore space and more compact, due to the low volume of manure. The total porosity (TP) of CMS was similar to that of Bd because of inverse relationship between $\mathrm{Bd}$ and TP (Table 4). The results showed that the CMS 3 treatment improved the bulk density, total porosity, and water-holding capacity. The physical properties of the cattle manure changed in different Particle sizes. This was due to the fact that small particles have smaller volumes, less pore spaces and more compact pattern. This would lead to improving total porosity, bulk density and water holding Capacity (Shulan et al., 2012).

Table 4. Some physical characteristics of different particle sizes of manure.

\begin{tabular}{cccc}
\hline Treatment & WHC\% & Bd g/cm $\mathrm{cm}^{3}$ & TP\% \\
CM & $9.34 \mathrm{c}$ & $0.39 \mathrm{c}$ & $60.40 \mathrm{a}$ \\
CMS1 & $10.84 \mathrm{c}$ & $0.42 \mathrm{c}$ & $58.30 \mathrm{a}$ \\
CMS2 & $16.29 \mathrm{~b}$ & $0.56 \mathrm{~b}$ & $44.00 \mathrm{~b}$ \\
CMS3 & $19.02 \mathrm{a}$ & $0.86 \mathrm{a}$ & $31.00 \mathrm{c}$ \\
LSD 0.05 & 1.70 & 0.055 & 5.25 \\
\hline
\end{tabular}




\subsection{Effect of Different Particle Sizes of Cattle Manure on Some Physical Properties of Sandy Soil}

Impact of different particle sizes of cattle manure (CMS) on total porosity (TP), bulk density $(\mathrm{Bd})$, pore size distribution and available water (AW) in pots and field is given in Table 5 and Table 6.

Table 5. Effect of different particle sizes of cattle manure on bulk density (Bd), total porosity (TP), available water (AW) and pore size distribution of sandy soil in pots experiment.

\begin{tabular}{cccccccc}
\hline \multirow{2}{*}{ Treatment } & AW & Bd g/cm & \multirow{2}{*}{$\begin{array}{c}\text { TP } \\
\%\end{array}$} & & \multicolumn{5}{c}{ Pore size distribution } \\
\cline { 6 - 8 } & & & & QDP\% & SDP\% & WHP\% & FCP\% \\
\hline Control & 0.52 & 1.39 & 36.0 & 53.7 & 42.0 & 2.7 & 1.7 \\
CM & 1.00 & 1.33 & 39.8 & 53.3 & 37.9 & 6.9 & 1.9 \\
CMS1 & 1.26 & 1.31 & 40.3 & 53.6 & 37.2 & 6.7 & 2.5 \\
CMS2 & 1.35 & 1.30 & 40.3 & 52.9 & 36.9 & 7.5 & 2.7 \\
CMS3 & 1.38 & 1.26 & 40.9 & 52.8 & 36.8 & 7.6 & 2.8 \\
LSD 0.05 & 0.48 & 0.02 & 3.7 & 6.75 & 4.1 & 1.5 & 1.2 \\
\hline
\end{tabular}

Table 6. Effect of different Particle sizes of cattle manure on bulk density (Bd), total porosity (TP), available water (AW) and pore size distribution of sandy soil in field experiment.

\begin{tabular}{cccccccc}
\hline \multirow{2}{*}{ Treatment } & AW & Bd g/cm & \multirow{2}{*}{$\begin{array}{c}\text { TP } \\
\%\end{array}$} & & \multicolumn{5}{c}{ Pore size distribution } \\
\cline { 6 - 8 } & & & & QDP\% & SDP\% & WHP\% & FCP\% \\
\hline Control & 0.93 & 1.48 & 39.10 & 49.46 & 48.22 & 1.30 & 1.02 \\
CM & 1.27 & 1.45 & 42.65 & 49.14 & 46.58 & 3.08 & 1.20 \\
CMS1 & 1.40 & 1.42 & 43.2 & 49.01 & 46.54 & 3.15 & 1.30 \\
CMS2 & 1.40 & 1.37 & 43.00 & 49.00 & 46.52 & 3.13 & 1.35 \\
CMS3 & 1.60 & 1.33 & 43.24 & 48.90 & 45.90 & 3.81 & 1.39 \\
LSD 0.05 & 0.35 & 0.03 & 3.17 & 4.23 & 1.30 & 0.70 & 0.64 \\
\hline
\end{tabular}

\section{Bulk density and Total porosity.}

The additions of CMS decreased soil Bd significantly compared to the control. The highest decrease was found with CMS 3 treatment the average values in pots and field $1.26 \%$ and $1.33 \%$, respectively. The addition of CMS significantly increased soil TP significantly compared with control. The highest total porosity value was observed at CMS 3 treatment in two experiments (pots and field). The average values in pots and field were 40.9 and 43.24 , respectively. The total porosity improved by using CMS compared to control. Soil bulk density (Bd) is one of the best values used as an indication for the status of sandy soil structure and the porosity is adversely associated with bulk density. Additions of the organic matter increased soil total porosity and decreased soil bulk density (Rochana et al., 2006; Shulan et al., 2012). This may be due to the improvement of 
the structural status of the soil. Similar conclusions were reported by (Doaa, 2012) who found that total porosity increased by organic matter application. Pore size distribution in soil was affected by different Particle sizes of cattle manure.

\section{Pore size distribution}

The treatments were decrease significantly in slowly drainable pores (SDP) compared to the control. The SDP reduction ranged from $9.76 \%$ at CM to $12.38 \%$ at CMS3 in the pots experiment, while reduction ranged from $3.4 \%$ at CM to $4.8 \%$ at CMS3 in the field experiment. Water-holding pores (WHP) increased significantly upon the addition of treatment compared to the control. The values of WHP in pots experiment for the control, CM, CMS1, CMS2, and CMS3 treatments were $2.7 \%, 6.9 \%, 6.7 \%, 7.5 \%$ and $7.6 \%$, respectively and in the field experiment these values were $1.3 \%, 3.08 \%, 3.15 \%, 3.13 \%$ and $3.81 \%$. This increased the value of such types of pores is an evident manifestation of the positive effect of organic matter addition on creating favored soil structure and forming pores which hold water useful for plant roots. The application treatments to the soil caused a slightly decrease in soil Quickly-drainable pores (QDP). This decrement of (QDP) was non-significant as compared to control in both experiments. The capillary pores (FCP) increased with the addition of treatment, but this increment of FCP\% was non-significant compared to the control. FCP in pots increased from $1.7 \%$ in control to $2.8 \%$ with CMS 3 application, while in field increased from $1.02 \%$ in control to $1.39 \%$ under the CMS 3 application. The above-mentioned results showed that addition of treatments increased water useful pores (WHP), and reduce the less water useful pores such as (QDP) indicating a better structure. The water holding pores (WHP) and slowly drainable pores (SDP) were the most positively affected by pores. WHP and SDP represent major parts of sandy soil porosity, and they are highly important in soil fertility and plant growth. These finding are in agreement with (EI-Maghraby et al., 2011; Francesc et al., 2016) who pointed out that adding an organic matter increased the number of small and medium sized pores, indicating a better structure and potential plant growth. Such changes in the pattern of pore size distribution would reflected in increasing water-holding capacity, and would certainly contribute to greater plant growth and ultimately higher grain yields (Ali, 2011). The Pore size distribution improved with decreasing particle sizes of cattle manure. This may be due to the small particles have smaller volumes, less pore spaces. This leads to entry it between sand grains.

\section{Available water (AW)}

Data presented in Table 5 and Table 6 indicated that addition of CMS significantly increased available water as compared to control in both pots and field. Also, results revealed that the values of AW significantly increased with decreasing particle sizes of manure. Available water in soils varies according to their bulk density and structure relationship to total pore size distribution. The organic matter improves available water in sandy soil. This may be due to the fact that organic substances attain a pronounced high content of active organic 
compounds that enhance the water molecules to be chelated (Moustafa et al., 2005). The Small particles have higher water holding than large particles this may be due to active organic compounds. These findings are in agreement with (Jiao et al., 2006; Mubarak et al., 2009; Rasoulzadeh \& Yaghoubi, 2010; Vengadaramana \& Jashothan, 2012) who found that addition of cattle manure increased aggregates soluble in water of a sandy soil. This means that an improved soil structure may have positive impacts on water holding capacity. Organic residues reduce water movement in sandy soil. This provides a better chance for crops to absorb water and nutrients rather than leaking.

\subsection{Effects of Different Particle Sizes of Manure on Fresh Weight, Dry Weight and Number of Leaf of Lettuce Plants}

Data in Table 7 showed that CM, CMS1, CMS2, and CMS3 treatments significantly increased the fresh weight, dry weight and number of leaf yield of lettuce plants as compared with the control. Fresh weight increased by $25.65 \%, 30.5 \%$, $33.00 \%$ and $35.60 \%$ at CM, CMS1, CMS2, and CMS3 respectively as compared with control. The highest dry weight was obtained at CMS3 followed by CMS2, CMS1, CM and control. Addition of organic matter as manure, proved to be an effective tool to soil fertility management in vegetables production. Perhaps this was due to improving the nutrient availability, nutrient holding capacity of soils, microorganism activity which effect of plant growth in sandy soils (Masarirambi et al., 2010; Mahmoud et al., 2013; Wendimu, 2016). The increase in fresh weight, dry weight and number of leaf yield might be due to that cattle manure in small particle sizes has a less half-life in soil (Aryanpour et al., 2017).

Table 7. Effect of different particle sizes of manure on lettuce.

\begin{tabular}{cccc}
\hline Treatment & Fresh weight $(\mathrm{g})$ & Dry weight $(\mathrm{g})$ & Number of leaf \\
\hline Control & 463.91 & 23.17 & 32.72 \\
CM & 582.94 & 29.14 & 37.76 \\
CMS1 & 605.44 & 30.28 & 41.05 \\
CMS2 & 617.02 & 30.84 & 44.91 \\
CMS3 & 629.08 & 31.48 & 47.29 \\
LSD 0.05 & 6.78 & 0.36 & 2.33 \\
\hline
\end{tabular}

\section{Conclusion}

In the present study, the sorption parameters of $\mathrm{N}, \mathrm{P}$ and $\mathrm{K}$ on different particle sizes of manure indicated that maximum sorption occurred on CMS 3 for both $\mathrm{P}$ and $\mathrm{K}$ according to Langmuir and Freundlich sorption models. The physical properties of cattle manure changed by particle size fractionation from (4.76 to $0.4 \mathrm{~mm}$ ), where the bulk density and water-holding capacity increased as total porosity decreased with decreasing particle sizes of manure. The different Particle sizes of cattle manure significantly affected bulk density, total porosity, pore size distribution, and available water in sandy soil with decreasing particle sizes 
of manure. Fresh weight, dry weight and number of leaf lettuce increased significantly with decreasing particle sizes of cattle manure as compared to control.

\section{Conflicts of Interest}

The authors declare no conflicts of interest regarding the publication of this paper.

\section{References}

Ali, L. K. M. (2011). A Study of Some Methods of Waste Management of Rice through Its Impact on Soil Physical Properties, N, P and K Contents in Maize Yield and Water Use Efficiency under Different Tillage System. Australian Journal of Basic and Applied Sciences, 5, 1017-1034.

Arthur, E., Cornelis, W. M., Vermangm, J., \& De Rocker, E. (2011). Effect of Compost on Erodibility of Loamy Sand under Simulated Rainfall. Catena, 85, 67-72.

https://doi.org/10.1016/j.catena.2010.12.005

Aryanpour, H., Naeini, S. A. M., \& Ahmadian, A. (2017). Application of Nano- and Micro-Sized Particles of Cattle Manure on Soybean Growth. Environmental Health Engineering and Management Journal, 4, 239-244. https://doi.org/10.15171/EHEM.2017.33

Bakayoko, S., Soro, D., Nindjin, C., Dao, D., Tschannen, A., Girardin, O., \& Assa, A. (2009). Effects of Cattle and Poultry Manures on Organic Matter Content and Adsorption Complex of a Sandy Soil under Cassava Cultivation (Manihot esculenta, Crantz). African Journal of Environmental Science and Technology, 3, 190-197.

Bayu, W., Rethman, N. F. G., \& Hammes, P. S. (2005). The Role of Manure in Sustainable Soil Fertility Management in Sub-Saharan Africa. Journal of Sustainable Agriculture, 25, 113-136. https://doi.org/10.1300/J064v25n02_09

Bhanu, C. D., Monisha, P., \& Bhaskara, R. I. (2018). The Effect of Soil Amendments on Physical Properties of Sandy Soils. International Journal of Agriculture Sciences, 10, 5095-5098. https://doi.org/10.9735/0975-3710.10.3.5095-5098

Black, C. A. (1982). Methods of Soil Analysis. Part 2. Chemical and Microbiological Properties (2nd ed.). Madison, WI: American Society of Agronomy.

Blake, G. R., \& Hartge, K. H. (1986). Particle Density. In A. Klute (Ed.), Methods of Soil Analysis (Part 1, 2nd ed., pp. 363-382). Agronomy Monograph 9, Madison, WI: ASA and SSSA.

Burt, R., Wilson, M. A., Kanyanda, C. W., Spurway, J. K. R., \& Metzler, J. D. (2001). Properties and Effects of Management on Selected Granitic Soils in Zimbabwe. Geoderma, 101, 119-141. https://doi.org/10.1016/S0016-7061(00)00100-2

Celik, I., Ortas, I., \& És Kilic, S. (2004). Effects of Composts, Mycorrhiza, Manure and Fertilizer on Some Physical Properties of Chromoxerert Soil. Soil and Tillage Research, 78, 59-67. https://doi.org/10.1016/j.still.2004.02.012

Cottenie, A. M., Verloo, L., Kiekens, G., \& Camerlynck, R. (1982). Chemical Analysis of Plants and Soils. Ghent: Lab. of Analytical and Agro. State Univ.

De-leenher, L., \& De-Boodt, M. (1965). Soil Physics. Ghent: International Training Center for Post Graduate Soil Scientists (ITC-Ghent).

Diana, G., Beni, C., \& Marconi, S. (2008). Organic and Mineral Fertilization: Effects on Physical Characteristics and Boron Dynamic in an Agricultural Soil. Communications in Soil Science and Plant Analysis, 39, 1332-1351. https://doi.org/10.1080/00103620802004037

Doaa, A. I. (2012). Effect of Organic Amendment and Potassium Fertilizing on Im- 
provement of a Salt Affected Soil and Wheat Yield. MSC Thesis, Tanta: Fac. of Agriculture, Tanta University.

EI-Maghraby, T. A., Abdel-Salam, M. A., \& Abdel-Warth, M. (2011). Effect of Compost on Maize (Zea mays) Yield and Some Clay Soil Physical Properties under Deficit Irrigation. Journal of Soil Sciences and Agricultural Engineering, 2, 611-622.

Eshwar, M., Srilatha, M., Bhanu Rekha, K., \& Harish Kumar Sharma, S. (2017). Characterization of Humic Substances by Functional Groups and Spectroscopic Methods. International Journal of Current Microbiology and Applied Sciences, 6, 1768-1774. https://doi.org/10.20546/ijcmas.2017.610.213

Francesc, D., Angela, D. B., Maria, R., Rosa, M., \& Jaume, B. (2016). Long Term Application of Dairy Cattle Manure and Pig Slurry to Winter Cereals Improves Soil Quality. Nutrient Cycling in Agroecosystems, 104, 39-51. https://doi.org/10.1007/s10705-015-9757-7

Giorgio, B. C., Francesco, P., \& Claudio, D. (2019). Effect of Biochar on the Physical and Structural Properties of a Sandy Soil. Catena, 175, 294-303. https://doi.org/10.1016/j.catena.2018.12.019

Inbar, Y., Hadar, Y., \& Chen, Y. (1993). Recycling of Cattle Manure the Composting Process and the Characterization of Maturity. Journal of Environmental Quality, 22, 857-863. https://doi.org/10.2134/jeq1993.00472425002200040032x

ISSS Working Group R. B. (1998). World Reference Base for Soil Resources: Introduction. In J. A. Deckers, F. O. Nachtergaele, \& O. C. Spaargaren (Eds.), International Society of Soil Science. Leuven: ISRICFAO-ISSS-Acco.

Ivajlo, I. B., Milanova, M. K., Velitchkova, N. S., Havezova, I. P., Velitchkov, S. V., \& Daskalova, N. N. (2008). Actively Coupled Plasma Atomic Emission Spectrometry Accuracy of Analytical Results and Detection Limits in the Determination of Race Elements in Soils and Sediments. Eurasian Journal of Analytical Chemistry, 3, 19-33. https://doi.org/10.1016/j.geoderma.2005.08.012

Jiang, H. et al. (2018). Seasonal and Long-Term Changes in Soil Physical Properties and Organic Carbon Fractions as Affected by Manure Application Rates in the Mollisol Region of Northeast China. Agriculture, Ecosystems \& Environment, 268, 133-143. https://doi.org/10.1016/j.agee.2018.09.007

Jiao, Y., Whalen, J. K., \& Hendershot, W. H. (2006). No-Tillage and Manure Applications Increase Aggregation and Improve Nutrient Retention in a Sandy-Loam Soil. Geoderma, 134, 24-33.

Kheir, A. M. S., Bayoumi, M. A., Marwa, G. M., \& Hegab, I. A. (2016). Economic Evaluation of Cereal Crop Production in Egyptian Sandy Soils. Journal of Chemical and Pharmaceutical Research, 8, 1003-1013. .

Klute, A. (1986). Water Retention. In A. Klute (Ed.), Methods of Soil Analysis Part 1 Physical and Mineralogical Methods (2nd ed., pp. 635-653). Agronomy Monograph 9, Madison, WI: ASA, SSA. https://doi.org/10.2136/sssabookser5.1.2ed.c21

Lata Verma, S., \& Marschner, P. (2013). Compost Effects on Microbial Biomass and Soil P Pools as Affected by Particle Size and Soil Properties. Journal of Soil Science and Plant Nutrition, 13, 313-328. https://doi.org/10.4067/S0718-95162013005000026

Mahmoud, R. A., El-Desuki, M., Abdel-Mouty, M. M., \& Ali, A. H. (2013). Effect of Compost Levels and Yeast Extract Application on the Pea Plant Growth, Pod Yield and Quality. Journal of Applied Sciences Research, 9, 149-155.

Masarirambi, T. M., Hlawe, M. M., Oseni, O. T., \& Sibiya, T. E. (2010). Effects of Organic Fertilizers on Growth, Yield, Quality and Sensory Evaluation of Red Lettuce (Lactuca 
sativa L.) "Veneza Roxa". Agriculture and Biology Journal of North America, 1, 1319-1324. https://doi.org/10.5251/abjna.2010.1.6.1319.1324

Matott, L. S. (2007). IsoFit Documentation and User's Guide. Version 1.2. New York: State University of New York at Buffalo, Department of Civil, Structural and Environmental Engineering.

Monica, O., Philip, A., Stansly, \& Teresa, P. S. (2011). Soil Chemical, Physical, and Biological Properties of a Sandy Soil Subjected to Long-Term Organic Amendments. Journal of Sustainable Agriculture, 35, 243-259.

https://doi.org/10.1080/10440046.2011.554289

Moustafa, M. A., Habashy, N. R., \& Anas, A. W. (2005). Utilization of Some Organic Polymers and Humic Acids for Improving a Sandy Soil Productivity of Peanut and Their Residual Effects on the Nex Crop of Faba Bean. Fayoum Journal of Agricultural Research and Development, 9, 42-55.

Mubarak, A. R., Omaima, E. R., Amal, A., \& Hamed, N. E. (2009). Short-Term Studies on Use of Organic Amendments for Amelioration of a Sandy Soil. African Journal of Agricultural Research, 4, 621-627.

Mylavarapu, R. S., \& Zinati, G. M. (2009). Improvements of Soil Properties Using Compost for Optimum Parsley Production in Sandy Soils. Scientia Horticulturae, 120, 426-430. https://doi.org/10.1016/j.scienta.2008.11.038

Rajashekhar, D., Srilatha, M., Chandrasekhar, R. P., Harish Kumar, S. S., \& Bhanu Rekha, K. (2017). Functional and Spectral Characterization of Humic Fractions Obtained from Organic Manures. International Journal of Pure \& Applied Bioscience, 5, 1254-1259. https://doi.org/10.18782/2320-7051.5454

Rasoulzadeh, A., \& Yaghoubi, A. (2010). Effect of Cattle Manure on Soil Physical Properties on a Sandy Clay Loam Soil in North-West Iran. Journal of Food, Agriculture \& Environment, 8, 976-979.

Rasoulzadeh, A., \& Yaghoubi, A. (2014). Inverse Modeling Approach for Determining Soil Hydraulic Properties as Affected by Application of Cattle Manure. International Journal of Agricultural and Biological Engineering, 7, 27-35.

Rochana, T. S., Rauysoongnern, P. V., \& Rambo, B. T. (2006). Effect of Organic and Clay Material Amendment on Physical Properties of Degraded Sandy Soil for Sugarcane Production. Sugar Tech, 1, 44-48. https://doi.org/10.1007/BF02943740

Shulan, Z., Liu, X., \& Duo, L. (2012). Physical and Chemical Characterization of Municipal Solid Waste Compost in Different Particle Size Fractions. Polish Journal of Environmental Studies, 21, 509-515.

Van Asperen, H. L., Bor, A. M. C., Sonneveld, M. P. W., Bruins, H. J., \& Lazarovitch, N. (2014). Properties of Anthropogenic Soils in Ancient Run-Off Capturing Agricultural Terraces in the Central Negev Desert (Israel) and Related Effects of Biochar and Ash on Crop Growth. Plant Soil, 374, 779-792. https://doi.org/10.1007/s11104-013-1901-Z

Vengadaramana, A., \& Jashothan, P. T. J. (2012). Effect of Organic Fertilizers on the Water Holding Capacity of Soil in Different Terrains of Jaffna Peninsula in Sri Lanka. Journal of Natural Product and Plant Resources, 2, 500-503.

Vijayaraghavan, K., Palanivelu, K., \& Velan, M. (2006). Biosorption of Copper (II) and Cobalt (II) from Aqueous Solutions by Crab Shell Particles. Bioresource Technology, 97, 1411-1419. https://doi.org/10.1016/j.biortech.2005.07.001

Wendimu, M. (2016). Effect of Farm Yard Manure Application Rate on Yield and Yield Components of Lettuce (Lactuca sative) at Jimma Southwestern Ethiopia. International Journal of Research-Granthaalayah, 4, 75-83. 


\section{Appendix}

Figure that illustrates the roadmap of experiments

Different particle sizes of cattle manure

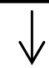

Batch biosorption of different Particle sizes of manure<smiles>C1C2CC12</smiles>

chemical properties of different Particle sizes of manure

$\downarrow$

Physical properties of different Particle sizes of cattle manure<smiles>[AlH2]</smiles>

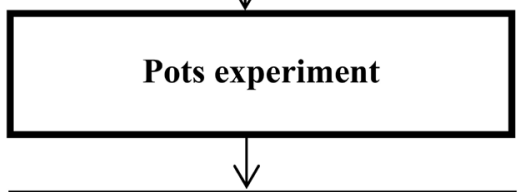

Field experiment 